\title{
Development Status and Challenges of Organic Rice Farming in Indonesia
}

\author{
Sujianto $^{1}$, Endro Gunawan ${ }^{2}$, Avishek Datta $^{3}$ \\ \{suj14nt0@gmail.com $\left.{ }^{1}\right\}$ \\ Asian Institute of Technology, Thailand ${ }^{1,3}$ \\ Indonesian Agency for Agricultural Research and Development, Indonesian Ministry of Agriculture, \\ Indonesia $^{2}$
}

\begin{abstract}
Rice (Oryza sativa) plays an essential role in Asian countries with $90 \%$ of world production, consumption, and stocks in this region, including Indonesia. The total of certified organic rice areas was increasing significantly from $1,142.3$ ha (2012) to be $3,152.5$ ha in 2016 , with the average growth of $21 \%$, annually. The main objective of study is to explore the new status of organic rice farming and identify the constraints, challenges, and opportunities addressed to the local and globalized world market. Organic rice production is still in the initiation stage, concentrated in populated islands, and cultivated in small spot areas produced unevenly over regions. Indonesian organic rice has many opportunities, challenges, and constraints. Many assessments showed that organic rice is more profitable than conventional rice due to its premium price, prospectus market both from domestic and international demand, and government support. Organic rice farming (ORF) is closely related to factors endowment suitability. Organic rice farming mostly has a different utilized variety. It has a minimum of information about technological cultivation, fertilization, and soil management. Some constraints are lack of organic fertilizer, land suitability, farmers' knowledge adopting GAP, and consumers' awareness. The critical challenge is how to cultivate organic rice with higher productivity while mitigating and decreasing the emission.
\end{abstract}

Keywords: Development, Organic Rice, Farming.

\section{Introduction}

Indonesia is the third-largest producer of paddy rice (Oryza sativa) in the world with the amount of production 74.2 million tons, sequence after China produced 210.2 million tons, and India produced 164.2 million tons in 2017 [1]. The total acreage of rice is $15,788,375$ ha, which consists of 14,632,646 ha wetland and 1,155,729 ha dry land [2]. The total produced rice is in line with the high domestic usage rate. Fulfilling the consumption for 262 million of its population, the government imported only 997.710 tons in 2016 or an estimated $1.2 \%$ of the total national rice consumption. It also makes rice become the most politically and economically important food crop for Indonesia. It frequently gets volatility price and disturbs national economic stability [3]. Moreover, Indonesian rice consumption per capita was relatively high, about $114.6 \mathrm{~kg}$ /capita [4]. It is higher than other producers of rice in Asian countries such as China, Thailand, and the Philippines, that have per capita consumption is $102 \mathrm{~kg}, 106 \mathrm{~kg}, 107.83 \mathrm{~kg}$, respectively [5][6][7]. 
In regional development, organic rice farming (ORF) is in line with the ASEAN food security and food safety agenda in the framework of promoting sustainable food production, providing food for the ASEAN Economic Community (AEC) [8]. It should gain equal attention to both economic and environmental aspect. Many researchers reveal that ORF is beneficial not only as an income generator for small farmers but also sustaining resources for future life. Against side, critical issue refers to rice farming that contributes $37.4 \%$ to the total Indonesian agricultural emission [9]. The essential challenge for organic rice farming is to adopt Good Agricultural Practices (GAP) for producing the excellent quality of rice. On another side, ORF should mitigate adversely effect on the environment. Therefore, it is essential to explore more detail about all endowment factors and constraints.

The Indonesian population becomes a prospectus of organic products for a domestic market. It is estimated that $65 \%$ of the total population is middle-up income that generates national economic growth and becomes the potential drivers contributing to the household consumption [10]. As a potential segmentation market, organic farming has a trend in the recent and future of Indonesian agriculture. This market chance will increase in line with the escalating demand for household consumption. The total of a certified organic area that rises significantly by $28.5 \%$ from $62,127.82$ ha in 2012 to $79,833.83$ in 2016 is indicating the intention of organic development [11][12]. The organic product has a function as a foreign booster exchange [13]. The total area of ORF was about 3,152.49 ha and produced 15,762.45 tons of paddy that showed a small number compared with national rice production [11].

The progress of Indonesian organic rice development is running slowly compared with the number of total domestic rice production. However, the government campaign of "go organic" has initiated since 2010. On another side, the considerable of middle and up income becomes a significant potential market, and the supporting endowment factors such as land, labor, and policies are a potential booster for pushing ahead the organic rice production. Therefore, it needs a review of what current status and essential factors influencing organic rice development profoundly. By knowing farmer action on the cultivation stage, we would know fundamental obstacles and challenges in practicing organic rice farming.

The main objective of this study was to explore the recent status of organic rice farming in Indonesia and critically identified constraints, challenges, and opportunities addressed to the local and globalized world market. Accelerating the adoption of organic rice farming needs a comprehensive understanding of cultivation techniques, the characteristics of farmers, marketchannel, and the performance of supporting agency. By this study, it is expected that the analysis situation about the current review would be a benefit for accelerating adoption. This article focus on the current status of organic rice practices in Indonesia due to the inherent strength, domestic, and global market demand.

\section{Research Methods}

This research is primarily based on the literature study and the structured in-deep interview with the involved organic rice actors, such as farmers, village traders, domestic traders, certification bodies and official governments. The duration study was conducted for six months from July-December 2018. Focus Group Discussion (FGD) of all actors was imployed to gain experience related to the opportunity, constraints, and challenges of ORF. For obtaining a more obvious depiction of organic experience, the head of groups of farmers at Subang regency, the director of Simpatic farmer Group, and the chief of farmer group in 
Tasikmalaya Regency were interviewed. Some data production and development of ORF were asked from the certification bodies and the Indonesian Ministry of Agriculture. The obtained data were recorded, classified, and arranged descriptively.

\section{Results and Discussion}

\subsection{Organic Farming Principles}

The fundamental concept of ORF is how to produce rice by avoiding synthetic fertilizer, pesticide, and growth promoter. IFOAM ditermine organic agriculture as a production system that sustains the health of soils, ecosystems, and people. Additionally, organic agriculture has a high prospect of mitigating climate change than conventional agriculture [14]. Organic agriculture is more environmentally sound because it adopts farm-level good agricultural practices (GAP) that avoid using synthetic input and Good Handling Practices [15].

Organic agriculture has four fundamental principles, namely: health, ecology, fairness, and care. In health, organic agriculture means sustaining and enhancing soil fertility, plant health, animal, and earth as an integral part. The ecological approach emphasizes ecosystem and cycles, work, emulating, and sustaining them. Fairness principle builds on a relationship that ensures equity, respect, and justice to the standard environment and life opportunities as a human. By caring for code, agriculture is managed in a precautionary and responsible way to protect the health and human of current and future generations and its environment [16]. These principles are the standard reference in management, application, and technological choice of organic agriculture. Due to the application of those principles, ASEAN countries work together to create a strategic plan of action (SPA) in term harmonizing the ASEAN standard for organic Agriculture (ASOA) from 2013-2015 [17]. In the broader region, a public-private partnership of stakeholders in East, South-East and South Asia through the project, led by FAO, IFOAM and the United Nations Conference on Trade and Development (UNCTAD) developed Asia Regional Organic Standard (AROS). This code is a principle reference to develop regional collaboration on organic cultivation, labeling, and trade [18].

\subsection{Indonesian Organic Rice Production}

Indonesian Organic Alliance (IOA) estimated that the total certified organic rice area in 2016 was about $3,152.49$ ha, equal to $15,762.45$ ton milled rice production. Organic rice is becoming the fourth largest organic product development produced by farmers with an amount less than coffee, honey, and coconut oil [11]. Coffee is 20 times bigger than rice production, and coconut oil is slightly higher than rice. Honey is collected and certified wildly from the wild nature and uncultivated yet. Therefore, organic rice has a big chance to develop prospectively. Table 1 shows some significant amounts of organic commodities in Indonesia. 
Table 1. Certified organic commodity area and production in Indonesia

\begin{tabular}{|c|c|c|c|c|c|c|}
\hline \multirow[b]{2}{*}{ Commodities } & \multicolumn{2}{|c|}{2013} & \multicolumn{2}{|c|}{2014} & \multicolumn{2}{|c|}{2015} \\
\hline & Area (ha) & $\begin{array}{l}\text { Production } \\
\text { (ton) }\end{array}$ & Area (ha) & $\begin{array}{l}\text { Production } \\
\text { (ton) }\end{array}$ & Area (ha) & $\begin{array}{l}\text { Production } \\
\text { (ton) }\end{array}$ \\
\hline Paddy rice & $1,537.20$ & $10,760.10$ & $1,194.60$ & $8,361.90$ & $1,753.70$ & $12,276.00$ \\
\hline Honey & $9,007.20$ & $2,702.20$ & $9,007.20$ & $2,702.30$ & $9,007.20$ & $2,702.20$ \\
\hline Coffee & $36,623.90$ & $109,871.70$ & $36,022.30$ & $108,066.90$ & $46,200.90$ & $346,200.90$ \\
\hline Cashew & $1,924.70$ & $1,539.70$ & $2,301.70$ & $1,841.40$ & $1,047.70$ & 838.10 \\
\hline Coconut oil & $1,277.90$ & 894.50 & $1,277.90$ & 894.50 & $2,390.60$ & $1,673.40$ \\
\hline Salacca & 225.80 & $1,061.10$ & 225.90 & $1,061.80$ & 184.10 & 865.50 \\
\hline Vegetables & 247.00 & $6,545.20$ & 234.10 & $6,203.90$ & 177.70 & $4,708.80$ \\
\hline Mangosteen & 106.70 & 853.40 & 52.00 & 416.20 & 318.00 & $2,544.20$ \\
\hline
\end{tabular}

The success of agricultural commodity adoption must be on its profitability. Farmers will adopt it based on their awareness. One of the research was in Banyumas regency that organic rice cultivation had Benefit-Cost $(\mathrm{BC})$ ratio 1.74 , total cost $\$ 523.9$ per ha, and total income $\$$ 910 per ha [19]. For organic red rice, the BC ratio was three times more than organic rice, and it had a high premium price [20]. Organic rice is undoubtedly profitable. Some researches argue that the productivity of organic rice is more than conventional rice. Even though on the conversion stage, it would be low productivity [21] [22]. In opposite, IOA calculated that the organic rice productivity average is $7.1 \mathrm{t} /$ ha paddy equal to $4.9 \mathrm{t}$ of rice [11]. It was higher than the national average of $5.4 \mathrm{t} / \mathrm{ha}$ [23] [1]. Organic rice plantings in high-latitude areas produced the high rice yield, which has the full light intensity, and was practicing intensive farming techniques [24].
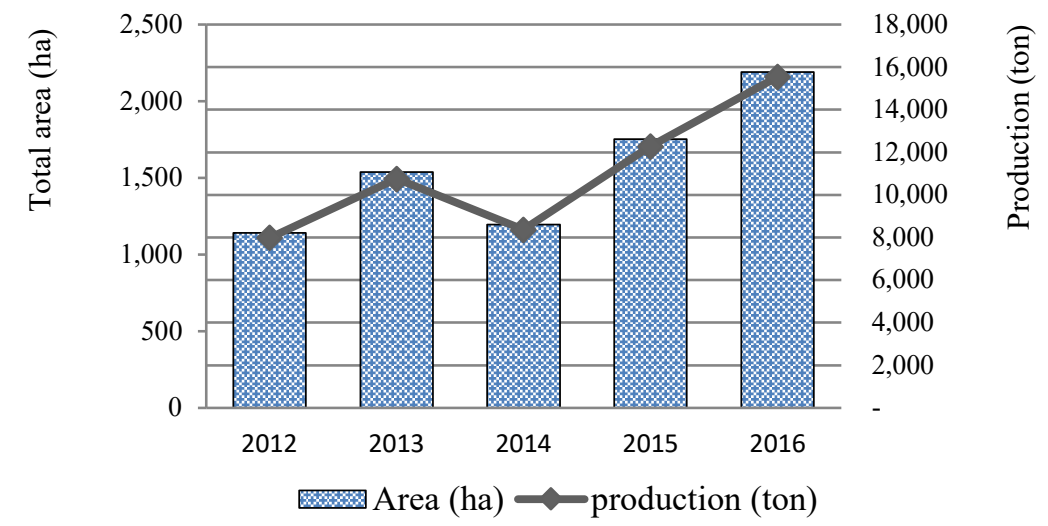

Fig. 1. Development of organic rice area and production in Indonesia ORF rice has the production area sporadically within 53 regencies in five islands, with the average area per region only about 41.3 ha. From the total of organic rice area $(3,152.5 \mathrm{ha})$, Java Island is the most significant number land with total area 891.94 ha of organic rice that consist of four provinces namely, Banten, West Java, Central Java, and East Java provinces. 


\subsection{Cultivation}

Farmers cultivated many rice varieties that differ from one location to another. It depends on the local demand and its culture. For example, ORF in Bali, farmers used to plant national and local variety. The national Indica varieties used are such as Ciherang $(49.6 \%)$, Cigeulis (31.7\%), IR-64 (2.1\%), Inpari 13 (10.2\%), and others (7.3\%). Even though local varieties have lower productivity than national varieties, some farmers planted local varieties, like Ijo Gading and brown rice, due to their taste preferences and religious ceremonial requirement [25]. In other provinces, Menthikwangi, local variety in Yogyakarta, is referenced by farmers in that region. In West Java, farmers usually cultivate Sarinah, Ciherang, Sintanur, Mekongga, and Pandan Wangi varieties [2]. Each location has different varieties of preference. It is closely related to endowment factors suitability, such as land, soil, and climate. Unfortunately, there is a lack of information related to the cultivation technique for each variety organically.

In some areas, farmers rotate their ORF with other commodities such as soybean (Glycine max), mung bean (Vigna radiate), and peanuts (Arachis hypogaea L.). Crop rotation has a benefit for conserving soil degradation, enhancing soil fertility, biological activities, and reducing the risk of pest. There are two kinds of organic rice production; parallel production and split production. Parallel production means that farmers plant organic and non-organic rice in one area. Meanwhile, split-plot production, farmers cultivate the land for many commodities, but some of them are not organic. For minimalizing unintended contamination, the organic area should have a buffer zone plants from other variety. If contamination is from water resources, a filtration treatment with size $0.1 \%$ from the total area should be made and planted by water hyacinth (Eichhornia spesiosa)[26].

In an ORF irrigation system, Farmers applied a water management system that concern with water efficiency and optimality. They used intermittent irrigation technology, and give intensive irrigation on 30 days after planting, to be dried when 45 days for fertilizing, and then give water $10 \mathrm{~cm}$ for decreasing the number of unproductive shoots [27]. Controlling water height is at an optimum level of $0.5 \mathrm{~cm}-2 \mathrm{~cm}$. In a particular period, water stress is given to keep root growth and new tillers. The water from the inorganic system must not contaminate organic land.

ORF apply fertilization management based on minimalizing external input and avoiding synthetic fertilizer. Burning straw, after harvesting time, is prohibited because it not only releases emission to the atmosphere but also kills microbes in the surface of the soil. Cultivating land and ameliorating soil can be done by mixing compost with byproducts from livestock. Preliminary, compost can be activated by beneficial microbe and fortified with a stone meal or shell powder with high mineral. Green manure also can be used for enhancing soil fertility and activating biological agents. If farmers use commercial products, the fertilizers must be certified organically. MoA recommends efficient fertilizer application of rice through Chart of Color Leaf (CCL) for N, Paddy soil test kit for P and K [28]. However, for organic rice, there is no recommendation available from the government. Farmers only used organic fertilizer such as petroganic brand with doses $500-1,000 \mathrm{~kg} / \mathrm{ha}$, which has $\mathrm{C}$ organic $12.5 \%$; $\mathrm{C} / \mathrm{N}$ ratio $10-15 ; \mathrm{pH} 4-8$; and water contain $4-12 \%$ or producing their fertilizer. Solid and liquid organic fertilizer were also highly recommended for rice organic farming [29]. Some results of the research showed that organic fertilizer also gives good growth on the plants. Liquid organic fertilizer made from Gliricidia leaves extract (Gliricidia sepium), then mixed with bran rice 1:10, added brown sugar and microorganism, can support ORF in good production [29]. The fertilization method is derived from Rice Intensification (SRI) that has principles improving the roots system through correct irrigation and enhancing 
soil fertility. The farmers used it without synthetic fertilizer, and chemical pesticides and used compost made by themselves [29]. Table 2 shows the distinction between organic SRI and conventional methods.

Table 2. Differences of management between organic SRI and conventional in Tasikmalaya regency, West Java

\begin{tabular}{lll}
\hline \multicolumn{1}{c}{ Factors } & \multicolumn{1}{c}{ Organic SRI } & \multicolumn{1}{c}{ Conventional } \\
\hline Seed planting & 12 days & $20-25$ days \\
Seed/hole & 1 & $3-7$ \\
Irrigation & $1 \mathrm{~cm}$ above soil surface & $5-10 \mathrm{~cm}$ above soil surface \\
$\begin{array}{l}\text { Fertilizer } \\
\text { Frequency of fertilization }\end{array}$ & $\begin{array}{l}\text { Compose } \\
\text { one time compos }+4 \text { times } M O L\end{array}$ & $\begin{array}{l}\text { Urea }+ \text { TS } \\
\text { (Local microorganism) }\end{array}$ \\
Resource of fertilizer & $\begin{array}{l}\text { Made by themselves or bought } \\
\text { from other villages }\end{array}$ & Shop \\
Control time & two times a day & $1-2$ time a day \\
Control activities & Water check, pest control & Water check and pest \\
\hline
\end{tabular}

Other cultivation factors are pest and harvesting management. Like other Asian countries, farmers often get primary insects attack like Brown planthoppers (BPH) (Nilaparvata lugens) cause unprecedented damage to rice. At the farm level, they often use pesticides to stop breakdown. Adversely, this method can destroy the balance of ecological biodiversities such as predators, bugs, spiders, and beneficial parasites and can make it resistant to insecticides. Through the adoption of ORF, it has a chance to cultivate more sustainable rice. It is in line with the IRRI agenda, sustainable rice platform (SRP), which focuses on reducing pest problems and cutting pesticide [30]. The fundamental strategy for pest management concept is focused on preventive action to avoid crop from disease and pest. In the harvesting, the ORF principle is avoiding contamination from the product not organically cultivated. There is no detail information related to the harvesting technique for ORF, and they do manual harvesting using tools such as a sickle knife and manual thrasher. Mechanization is one of the essential ways of increasing productivity and quality. It has a benefit for human resource capacity in the production from all steps from the seedling to the harvesting activities [30]. The decreasing of human labor for planting rice seeds frequently affects to schedule delay of planting, and the seed becomes over old.

\subsection{Farmers' Characteristics}

The farmers' characteristics have effects on the speed of ORF adoption. There is a corelation between the level of age, education, acreage of land ownership, and income to the positives factor adoption on organic rice in Southeast Minahasa Regency, Indonesia [31]. In other research related to the adoption of ORF, land suitability and gained profit had a strong correlation to the level of adoption [31]. Additionally, land tenure and ownership will determine of adoption of organic rice farming. The decision can be alternative, collective, or authority [22]. It can be a constraint for people who want to shift to organic but limited by their authority. The adoption of tenant farmers depends on their perception of organic farming.

Moreover, farmers have limited land for cultivating organic rice. The average of land ownership in Indonesia is about 0.67 ha (low land) and 0.50 (upland) [32]. In Boyolali Regency, Central Java, Organic rice farmers adopted farming systems through the sequential 
stage from the knowledge, belief, decision, confirmation, and adoption [33]. Farmers' knowledge was related to the information of local varieties and their cultivation gained from extension officers. Participating in field school made them in the belief stage. All information then persuades them to continue to the decisional level to adopt.

\subsection{Trading System and Market}

Organic producers are still focusing on big cities and dominated by the organic rice market. Price volatility sometimes happens to the organic rice market, but not significantly to other products like vegetables and fruits. In Bali, there was a lack of recognition related to certification and organic product labeling [25]. The products that stick by organic label had a significantly higher price than conventionally rice. Irresponsible traders used conventional rice products labeled as organic rice. It must be reducing consumers' trust in organic products. However, for producing organic products, producers have to conform to all regulations and rules through a lengthy certification process, assessment, and gaining label correctly.

At least 15 researchers had topics related to the consumers' preferences and their behavior on organic rice in Indonesia. The main preferences, why they chose organic rice are healthy, no pesticide, nutritious, taste, non-GMO, support small farmer income, anti-modern farming, and environmental concern [34]. Health motivation is a very significant main reason for consuming organic rice [35]. General attributes as consumers concern are price, taste, quality guarantee, and availability. Price is a determination decision to select organic products. The price of the organic product is relatively higher than non- organic product [19]. Organic rice price is relatively expensive and becomes an essential constraint to the buying interest of organic rice [36]. Additionally, the number of imported premium rice indicates the unmanaged local market. Government still imported jasmine rice, basmati rice, sushi rice, rice with a low glycemic index. Private sector companies holding a producer importer identification number can import specialty rice once an import approval from the ministry of Trade obtained [37]. There is no great effort to substitute imported rice with organic rice produced locally. The national organic rice has barriers to the supply chain, including the production system and other chains in the supply chains. If we can remove the barriers, then the advantage taking of the world's organic rice demand can proceed.

\subsection{Certification and Institutional Supports}

The certification is still a voluntary obligation. There are three guarantee systems: selfdeclare, community declares, and organic certification body. Self-declare means that the farmers cultivate their crops based on principles of organic production and declare their product organically. Second, community guarantee means the monitoring and supervision of association. In this case, the Indonesian Organic Alliance is in charge of developing this certification and well known as PAMOR. PAMOR is a participatory guarantee system that involved producers, NGOs, Government, and consumers [11]. IFOAM introduced PGS (Participatory Guarantee System) as one of the alternative organic guarantees that locally focuses on quality assurance system [11]. Third, certification is through the third party as a certification body, such as INOFICE, PT. BioCert Indonesia, Mutu Agung Lestari (MAL) Sucofindo, PT.Persada, LeSOS, and LSO West Sumatra [4]. Most of them operate for domestic organic products, with $21 \%$ of total certification in Indonesia. While, International certification bodies that are accredited by IFOAM and have operation country of Indonesia are Australian Certified Organic (ACO Certification, LTD); Biocert International Pvt. Ltd., hosted 
country in India; NASAA Certified Organic (NCO), Australia; Organic Agriculture Certification Thailand (ACT); Organic Food Development and Certification of China (OFDCC) [4].

\subsection{Constraints and Challenges}

ORF has technical constraints such as limited organic fertilizer, difficulties preventing contamination water, and cost of organic certification. The domestic organic fertilizer is still not enough for national consumption. Farmers should make their fertilizer from compost, dung, green manure, and active microorganism. Farmers have a minimum of government endorsement and scaling up an opportunity. Organic rice also has market and consumer behavior constraints [4]. Even though the market demand for organic rice is increasing, the consumers still assume that organic rise is expensive due to buyer power parity [15]. It was a strong correlation between increasing allocating of buyers' organic budget with lowering consumption as alternative ways to mitigate climate change [38].

ORF has some challenges, such as emission issues addressing rice cultivation, farmers' knowledge, cost rationality, supporting policies, consumer awareness. SRI cares about water management and soil treatment, but SRI is also using organic fertilizer, especially green manure, that high sharing to the emission. Moreover, the claim of rice production gave about $37 \%$ of total agricultural emission 143,682.86 gigagrams [9]. One of the significant challenges in organic rice is how to produce high yield and quality and to mitigate emission in all cultivation processes. ORF had less GHG emissions due to avoiding synthetic fertilizer and pesticide, but it had extra emissions from the organic fertilizer that offered the primary source of methanogen compound [39].

\section{Conclusion}

Exploring the status of organic rice farming related to identifying the opportunities, challenges, and constraints of organic rice addressed to the local and globalized world markets, organic rice farming in Indonesia is still on the infant stage, which is proliferating. It has many opportunities, such as profitability due to a higher price, consumers' demand, and government support. It has practical constraints, such as fertilizer availability, land suitability, improving farmers' knowledge, and increasing consumer care to organic products. Meanwhile, the challenges of developing organic rice farming are producing high productivity while reducing emission to the environment.

\subsection{Recommendations}

Government policies should focus on building the center of organic rice farming. For making a stable market brand, Indonesian ORF needs to promote USP (Unique Selling Proposition) branding like Jasmine rice (Thailand) and Basmati rice (India). It might be an aromatic rice brand that differentiating products which cultivated organically in fertile soil and specific climatic condition. From this study, there is some future research, namely: (1) each organic area has its characteristics and specialties such varieties, cultivation technique, water management, fertilization, and soil fertility. Therefore, it is needed to find alternative agricultural practices that suitable for their land; (2) ORF should promote fairness for all 
actors within the system include labor. It needs to assess whether the supply chain of ORF in state of fairness, especially for the farmers.

\section{References}

[1] FAO, "FAO Rice Market Monitor (RMM), Volume XXI, Issue No. 1,” 2018.

[2] I. M. of A. MoA, Agricultural statistics 2017. 2017.

[3] J. Mariyono, "Green revolution- and wetland-linked technological change of rice agriculture in Indonesia," Manag. Environ. Qual. An Int. J., vol. 26, no. 5, pp. 683-700, 2015.

[4] I. M. of A. MoA, "Organic Certification Bodies In Indonesia.” 2017.

[5] L. S. Grace Bersales, Agricultural Indicator System (AIS): Food Consuption and Nutrition. Philippine Statistics Authority, 2017.

[6] R. Santella and P. Prasertsri, "Thailand Grain and Feed 2016," 2016.

[7] Z. Zhou, W. Tian, J. Wang, H. Liu, and L. Cao, "Food consumption trends in China.," 2012.

[8] X. Choulamany, Issues and Strategies to Assure Food Security in ASEAN ( ASEAN Level Initiative on Food Security ). 2010.

[9] FAOSTAT, "Indonesian agricultural emission by activities." 2016.

[10] Worldbank, "Indonesian middle class vital for the country future," 2017.

[11] AOI, Statistik Pertanian Organik Indonesia. 2017.

[12] FiBL, "Key indicator of organic world wide by countries : Indonesia," 2016.

[13] E. Rehber and S. Turhan, "Prospects and challenges for developing countries in trade and production of organic food and fibers: The case of Turkey," Br. Food J., vol. 104, pp. 371-390, 2002.

[14] K. M. Goh, "Greater mitigation of climate change by organic than conventional agriculture: A review," Biol. Agric. Hortic., vol. 27, no. 2, pp. 205-229, 2011.

[15] I. W. Budiasa, "Organic farming as an innovative farming system development model toward sustainable agriculture in Bali," Asian J. Agric. Dev., vol. 11, no. 1, pp. 65-75, 2014.

[16] IFOAM, "Principles of Organic Agriculture," Ifoam, p. 5, 2005.

[17] ASEAN Secretariat, "ASEAN Standard for Organic Agriculture (ASOA)." pp. 1-15, 2014.

[18] Global Organic Market Access (GOMA), Asia Regional Organic Standard (AROS). UNTAC, FAO, \& IFOAM, 2012.

[19] A. Hartati and D. Putri, "Strategi pengembangan model pemasaran beras organik berbasis consumer' s market di Kabupaten Banyumas," SEPA, vol. 13, no. 1, pp. 1-9, 2016.

[20] L. A. Dewi, I. G. Agung, A. Ambarawati, and I. W. Budiasa, "Strategi pengembangan agribisnis beras merah organik di Subak Wongayabetan, Desa Mengesta, Kecamatan Penebel," vol. 4, no. 1, pp. 37-46, 2016.

[21] M. Syam, "Padi organik dan tuntutan peningkatan produksi beras," Iptek Tanam. Pangan, vol. 3, no. 1, pp. 1-8, 2008.

[22] M. A. Heryanto, Y. Sukayat, and D. Supyandi, "Model behaviour of farmers in the adoption of rice organic farming system : paradox of socio - economic - environmental," vol. 18, no. 2, pp. 159-165, 2016.

[23] I. S. B. BPS, "Indonesian rice productivity." 2015.

[24] G. P. (eds) Maclean, J.L., Dawe, D.C., Hardy, B. and Hettel, Rice almanac. Third Edition, vol. 92, no. 5. 2013.

[25] F. Shiotsu, N. Sakagami, N. Asagi, D. N. Suprapta, N. Agustiani, Y. Nitta, and M. Komatsuzaki, "Initiation and dissemination of organic rice cultivation in Bali, Indonesia," Sustain., vol. 7, no. 5, pp. 5171-5181, 2015.

[26] BSN, “SNI 6729:2016, Sistem pertanian organik.” Jakarta, pp. 1-16, 2016.

[27] R. Malia and H. G. Putra, "Tingkat adopsi petani terhadap penerapan padi pandanwangi organik," vol. 7, no. 2, pp. 253-261, 2017.

[28] MoA, "Permentan No 40,2007 Rekomendasi pemupukan N,P,K padi sawah spesifik lokasi." 
2007.

[29] I. Y. Supartha, G. Wijaya, and G. M. Adnyana, "Aplikasi jenis pupuk organik pada tanaman padi sistem pertanian organik," E-Jurnal Agroekoteknologi Trop., vol. 1, no. 2, pp. 98-106, 2012.

[30] IRRI, "Reducing pest problems and cutting pesticide," IRRI, 2018.

[31] W. M. Wangke and L. S. Benu Olfie, "Adopsi petani terhadap inovasi tanaman padi sawah organik di Desa Melompar Kecamatan Tombatu Timur, Kabupaten Minahasa Tenggara," AgriSosioEkonomi Unsrat, vol. 12, no. 2 Mei, pp. 143-152, 2016.

[32] I. M. of A. MOA, "Renstra Kementrian Pertanian Pertanian Tahun 2015 - 2019," 2014.

[33] A. Triyono and W. M. Rahmawati, "Adopsi inovasi budidaya padi organik pada petani di Kelompok Appoli ( Aliansi Petani Padi Organik Boyolali )," URECOL, Univ. Res. colloqium, pp. 417-428, 2018.

[34] D. P. Utami, "Analisis pilihan konsumen dalam mengkonsumsi beras organik di Kabupaten Sragen," Mediagro, vol. 7, no. 1, pp. 41-58, 2011.

[35] P. Sulistyana, J. H. Mulyo, J. Sosial, E. Pertanian, F. Pertanian, U. G. Mada, F. Pertanian, and U. G. Mada, "The Consumption of organic rice in the household level at Yogyakarta City (back to nature)," vol. 24, no. 1, 2014.

[36] N. Idaman, L. N. Yuliati, and Retnaningsih, "Sikap konsumen terhadap beras organik," $J$. Manaj. Agribisnis, vol. 9, no. 2, pp. 117-126, 2012.

[37] G. McDonald and S. Meylinah, "Indonesia grain and feed annual report 2018," GAIN Rep. Number, vol. ID1808, 2018.

[38] L. R. Heerwagen, L. M. Andersen, T. Christensen, and P. Sandøe, "Can increased organic consumption mitigate climate changes?," Br. Food J., vol. 116, no. 8, pp. 1314-1329, 2014.

[39] H. C. Lin and Y. Fukushima, "Rice cultivation methods and their sustainability aspects: Organic and conventional rice production in industrialized tropical monsoon Asia with a dual cropping system," Sustain., vol. 8, no. 6, 2016. 